\title{
Heliopolis: Lisa Jarnot's rewriting of a legendary city
}

\begin{abstract}
In her second book Ring of Fire, American poet Lisa Jarnot offers the reader a dynamic sixteen-poem sequence entitled Heliopolis. Jarnot's Heliopolis uses the legendary City of the Sun as a starting point, but rather than describe or depict the life of antiquity, Jarnot considers the city as an ongoing posthuman vortex where animals perform a range of implausibly or absurdly anthropomorphic actions. Moreover, Jarnot's recursive poetic structures both heighten the rhythmic and ludic qualities of the actions described while toggling between poignant humor and ethical confrontation. This essay seeks to examine what the social and ethical implications are in Jarnot's reimagining of this legendary city. Moreover, the work of Cary Wolfe, Donna Haraway, and others within posthumanist discourse will be considered as a critical lens into how Jarnot is leveraging playfulness and anthropomorphism. Why does Jarnot consistently (re-)present non-human animals in her poems? How do her stylistic gestures collapse distinctions between physical and temporal boundaries?
\end{abstract}

Keywords: Heliopolis, American poetry, posthumanism, animals, experimental poetry.

\section{Introduction}

Although animals have been a recurring subject throughout her oeuvre, in her second full-length book, Ring of Fire, renowned American poet and biographer Lisa Jarnot offers the reader what is perhaps her most sustained poetic exploration of nonhuman animals: Heliopolis, a sixteen-poem portfolio. The sequence features a wealth of poems about animals historically underrepresented in literature-aardvarks, chinchillas, lemurs, razorback clams-as well as animals with more established historical and artistic representations, such as cows and dogs. Regardless of the particular species, Jarnot's animals perform a range of implausibly or even absurdly anthropomorphic actions: arctic birds stroll through New York City and hail cabs; wolves live in houses with heaters, stoves, and TVs; lemurs love tools and all outer space; and aardvarks fill hotel rooms and take train rides. Coupled with the actions of the animals, Jarnot deploys

1 Address for correspondence: Dept. of North American Literature \& Culture, Faculty of Philology, University of Lodz, ul. Pomorska 171/173, 90-236 Lodz, Poland. E-mail: mark.tardi@uni.lodz.pl 
recursive structures within the poems that both amplify the rhythmic and ludic qualities of the actions described, but also toggle between comical and ethical confrontation.

This essay seeks to consider what the larger social and ethical implications are in Jarnot continually (re-)presenting these nonhuman animals in her poems, and, more specifically, what these representations might demonstrate in Jarnot's vision of the legendary city Heliopolis. First, some historical context to the ancient city of Heliopolis will be established and elaborated on. Secondly, the essay will pivot to a general overview of the critical reception of Jarnot's work in Ring of Fire, and the formal qualities in the poems. Thirdly, the relationship between the more explicit animal poems and the later poems in the sequence Heliopolis which explore human speakers and what it means to be human will be compared and contrasted in light of Jarnot's conceptualization of Heliopolis. Lastly, I will explore how her poems might step beyond their initial absurdist elements, and how the poems may comport with prevailing ideas and concepts within posthumanist discourse. Although her formal structures are reminiscent of Gertrude Stein, how does Jarnot extend beyond nonlinearity to leverage playfulness and anthropomorphism as a platform for profound social criticism? Moreover, how does her conceptualization of Heliopolis reframe history and offer a path to reconsider what constitutes the human(e)?

\section{Cleopatra's Needles}

The ancient city of Heliopolis served as an important and influential religious and philosophical center in Egypt. Daniel Thompsett (2014: n.p.) explains that:

As the purported site of the advent of 'being' and the beginning of all existence, it is not surprising that Heliopolis gained notoriety as a community of priests who studied philosophy and astronomy, becoming the main center in Egypt for ancient learning and theology prior to Alexandria's rise.

Agnieszka Dobrowolska and Jarosław Dobrowolski (2006:15) further note in Heliopolis: Rebirth of the City of the Sun that "[o]f the four separate cosmogonies that originated in Egypt's different religious centers, the one that developed in Heliopolis was the earliest, and it continued to influence theologians." This was a city built around sun-worship, hence the name "Heliopolis" literally means "the City of the Sun" (Dobrowolska \& Dobrowolski 2006: 16). Moreover, the city's reputation grew as a center for learning courtesy of effective mythologizing. Strabo, the ancient Greek geographer, historian, and philosopher, visited Heliopolis because "he was following in the footsteps of his great mentors (or at least he believed so)": it was thought that Eudoxus of Cnidus and Plato visited Heliopolis to learn from priests who "were distinguished in their knowledge of heavenly bodies" (Dobrowolska \& Dobrowolski 2006: 27-29). 
Thus, Heliopolis increasingly became a synthesis of Egyptian and Greek ideas, and one of the most notable exports was the obelisk, which appears to have been invented in the City of the Sun. The obelisk is "the only significant surviving remnant of the ancient city and its grand temple" (Dobrowolska \& Dobrowolski 2006: 16). The obelisks themselves were a source of wonder that prompted voyagers to travel great distances to catch a glimpse of them, particularly at dawn: "the obelisks' shining metal tips of precious metal would catch the first rays of the sun high above a land still engulfed by night. For many centuries they would continue to inspire awe and fascination" (Dobrowolska \& Dobrowolski 2006: 16). Perhaps the most famous of the Heliopolitan obelisks are the twin Cleopatra's Needles: built more than 3,500 years ago, they were first moved by Caesar Augustus in 12 BCE and are still standing today. One was relocated to London in 1877; and the other was transported to New York in 1879 (Dobrowolska \& Dobrowolski 2006: 17-19).

For Jarnot, these various Heliopolitan characteristics are reconfigured and relocated to the late 20th century or early 21st century in her poems. There are numerous references to heavenly bodies and light and the locations of Jarnot's poems in her Heliopolis lean heavily towards the contemporary cities that harbor Cleopatra's Needles as well as another location that retains an Egyptian obelisk, Paris. Given the wealth of references and allusions in Jarnot's poetry, it is reasonable to suggest that, much like Heliopolis, Jarnot's poems aim to function as a repository for knowledge on our contemporary moment. In addition, if ancient Egyptian religious practices celebrated a kind of synthesis between human and nonhuman animals, Jarnot adds to those considerations humor and anthropomorphism as critique, as we shall see.

\section{A Veritable Zoo}

Upon its publication, the critical attention was considerable for Lisa Jarnot's second fulllength collection, Ring of Fire, although views were split. Writing for the Boston Review, award-winning poet and translator Andrew Zawacki (2002: 3) observed that:

the objects of Jarnot's affection include a veritable zoo of raccoons, lemurs and yaks, a chinchilla and an armadillo, polar bear, hippo, chicken, ocelot, monkey, "an albatross in the hottubs of dawn," and "ferocious the giant / squirrels." Jarnot's ebullient repetitions, though, become a tic, and Ring of Fire comprises eighty pages of unmitigated tidal rhetoric. It may be that such in-and-out most accurately and sonorously mimics a meditative procedure, or the obsessions of a mind at the end of its tether. But as an aesthetic strategy, the compulsion to repeat risks abrading the reader, who feels he's becoming a patient, impatient.

Zawacki recognizes the sheer variety of animals represented in Jarnot's collection, but his critical focus is on the sonic and formal effects of the poems. For Zawacki, Jarnot's 
repetitions and recursions are more irksome than meditative. Conversely, esteemed poet and publisher Devin Johnston² (2002: 141) argued in the Chicago Review that:

Though these poems are populated by playful aardvarks and lemurs, and often move sideways through dream narratives, they are also very much a record of living. One finds not only the pleasures of what's new, but the pleasures of recognition... Jarnot's repetition is thus accretive-not minimalist but maximalist-and the self speaking in these poems aims at some of Whitman's expansiveness.

Although these two critics have opposing views on the aesthetic merits of Jarnot's formal strategy, they both see a connection to Whitman in Jarnot's poetry-and, perhaps unsurprisingly, come to quite different conclusions. For Johnston, the poems in Ring of Fire are a "record of living," and Jarnot's formal strategy-like Whitman's-is "accretive." Zawacki (2002: 2), however, detects in Jarnot that "her acts of being numerous, her rage to compass the world" are ultimately "rendered untenable" as "the speaker finally seems exhausted at her inability to incarnate herself once and for all". What is more, both critics note Jarnot's formal strategies-“dream narratives" for Johnston; "tidal rhetoric" for Zawacki- and animals as subject matter but neither of them observes or considers ecology or empathy as animating Jarnot's poetic project.

\section{A Bunch of Solar Heat-Stored Up and Organized}

Lisa Jarnot's Heliopolis, is a sixteen-poem portfolio within the book Ring of Fire, and includes poems with titles such as Suddenly, Last Summer; Ye White Antarctic Birds, O Razorback Clams; Moo is Om Backwards; Song of the Chinchilla; You, Armadillo; On the Lemur; and simply, Aardvark. Looking at the individual poem titles alone, it is readily apparent that nonhuman animals will play part in the narratives. And given the title of the sequence overall-Heliopolis-Jarnot is giving the reader a key conceptual marker for how the parts may connect with the larger whole.

The poem Suddenly, Last Summer begins the sequence and-like the ancient travelers to the ancient Heliopolis-starts with night equated to absence as well as starkly contrasted with the warmth of the sun:

Sun worshipper I, in the absence of the sun, in the

things I don't remember, the unfriendliness of night,

the neon night and the blue blue night, the creatures

2 In light of his review of Ring of Fire, it is perhaps not surprising that Devin Johnston went on to publish Jarnot's next two volumes, Black Dog Songs and Night Scenes with his press, Flood Editions. 
on the beach,

Suddenly, to remember the sun and all the creatures

on the beach, suddenly to remember the sun and

little sunstroked turtles, suddenly the neon night

surrounding little turtles all surrounded by the night

upon the turtles on the beach (Jarnot 2001: 53)

Here night is "unfriendly" and blamed for a loss of memory, while the sun is both something worshipped and brings to mind "all the creatures / on the beach." The speaker seems to be echoing a sentiment by the famous French post-Impressionist painter Paul Cézanne, who once remarked that "We are nothing but a little bit of solar heat stored up and organized, a reminder of the sun, a little phosphorus burning in the meninges of the world" (Maso 1995: 146). Thus, from the very start, Jarnot's conceptualization of Heliopolis moves to put human and nonhuman animals as vital subjects coexisting and interdependent. And as Deleuze and Guattari (1987: 233) argue, "One of the main problems of natural history was to conceptualize the relationships between animals." It is clear from the poem that this "Heliopolis" is not a purely ancient one, as it presents the far more contemporary "neon night," and Jarnot's reconstruction of historical dynamics echo Deleuzian concerns.

In Life Force of Supernalness of World, the speaker celebrates the "head gear of the subway trains in / spring, o the day I saw Lou Reed / on a side street near 6th Ave, o / jubilance of paper cuts and paper / clips and snow" (Jarnot 2001: 54). The reader is left to consider that this world, this Heliopolis, is one in which celestial qualities ("supernalness") are celebrated and which may resemble (or be) contemporary New York. Similarly, Ye White Antarctic Birds are, in fact, "birds of upper 57th Street," which again locates the poem in New York (Jarnot 2001: 55). Given that New York is where one of Cleopatra's Needles is located, the link between the modern metropolis and the ancient Heliopolis is perhaps not such grand leap.

Beginning with "Because it is sad," the poem O Razorback Clams offers a kind of empathetic lament for the restaurant experience and forces the reader to navigate an ambiguous point of view from the speaker. Does the "it" in the opening line refer to the general phenomenon of going out to eat? Is the "it" a razorback clam? Something else? Later the melancholy is located in menus, hunger, food itself, and a single declarative "I am sad," which may be the voice of a clam. The poem closes by comparing razorback clams to "sad and lonely lobsters as they / wave inside the oceans in the breeze" (Jarnot 2001: 57). Already just a few poems into the sequence, Jarnot slides between macro- and micro-scales-of time, place, and social dynamics-a formal strategy that continues as the sequence unfolds. 


\title{
If they exhaust noise and distance and even dust
}

Although critics identify repetition as a key element in Jarnot's poetics, the influence of Gertrude Stein is largely unremarked upon. Consider just a brief example from Stein's Modernist classic, Tender Buttons:

\begin{abstract}
A Red Stamp
If lilies are lily white if they exhaust noise and distance and even dust, if they dusty will dirt a surface that has no extreme grace, if they do this and it is not necessary it is not at all necessary if they do this they need a catalogue. (Stein 1914: 6)
\end{abstract}

In A Red Stamp and elsewhere in Tender Buttons," Stein-like Jarnot-deploys accretion and nonstandard punctuation to create a propulsive momentum in the poems. The use of the conditional "if" in A Red Stamp undercuts or confounds causal relationships. How can a color ("lily white") "exhaust noise?" And the last two lines demonstrate the effects of adding a few words to an existing phrase: "it is not necessary it is not at all necessary" or "if they do this... if they do this they need a catalogue." The formal parallels with Jarnot are abundant, however, there are some significant differences as well.

For starters, one cannot reasonably claim that there is an obvious mimetic or ekphrastic function in Tender Buttons. Instead, repetition, recursion, and pivots advance or propel the poem forward. The relationship between the titles of Stein's poems and the texts themselves is profoundly abstract, with the poems functioning more like nonlinear Cubist still lifes than any kind of descriptive subject matter. As Marjorie Perloff (1979: 42) explains:

a text like Tender Buttons can be exasperating and boring if one expects to find actual descriptions of the objects denoted by the titles.... Rather, the author offers us certain threads which take us into her verbal labyrinth, threads that never quite lead us out on the other side but recreate what [John] Ashbery calls 'a way of happening.'

This stands in stark contrast to Jarnot's poems, which more explicitly link their titles to the subjects of the poems. Formally, Jarnot accepts the dynamism of recursion and repetition but Stein's level of abstraction stands in the way of one of Jarnot's other aims, to render nonhuman animals more visible. Instead, a poem like Moo is Om Backwards ${ }^{3}$

3 As I have written elsewhere about this poem: "Jarnot uses the notion of a mantra as both rhythmic guide and anagrammatic mirror, the title both referencing the sound a cow makes "Moo") as well as mediative repetition ("Om, Backwards"). The formal maneuvering in the poem is incremental, and small changes aggregate as the poem progresses-similar to structures that Minimalist composers such as Philip Glass or Arvo Pärt use in their music making slight additions to an initial string of notes-begin- 
seems to offer a response to Deleuze and Guattari (1987: 151) when they wonder, "Why not walk on your head, sing with your sinuses, see through your skin, breathe with your belly: the simple Thing, the Entity, the full Body, the stationary Voyage, Anorexia, cutaneous Vision, Yoga, Krishna, Love, Experimentation”. To which Jarnot writes:

That the cows moo in the field, that the cows moo in the field quite loudly, that the cows are mooing in the field, that in the field the cows are mooing, that I love things, that they love me back, that the cows all love each other and the daisies, that the daisies love each other and the cows, that by loving in transcendence there are cows and there are daisies that they love... (Jarnot 2001: 58)

Moreover, the celebratory micro-symbiotic relationship between cows, daisies, music, and reader poetically dramatize posthumanist theorist Donna Haraway's (2008: 3-4) assertion that:

I love the fact that human genomes can be found in only about 10 percent of all the cells that occupy the mundane space I call my body; the other 90 percent of the cells are filled with the genomes of bacteria, fungi, protists, and such, some of which play in a symphony necessary to my being alive at all, and some of which are hitching a ride and doing the rest of me, of us, no harm. I am vastly outnumbered by my tiny companions; better put, I become an adult human being in company with these tiny messmates. To be one is always to become with many... I love that when "I" die, all these benign and dangerous symbionts will take over and use whatever is left of "my" body, if only for a while, since "we" are necessary to one another in real time.

Critic David Kaufmann (1999: 2) adds that “[Jarnot's work] shows quite clearly how the same words can have quite different uses, at the same time that it raises the question of the relation between identity ( $\mathrm{am}$ ) and action (I am doing)". In Jarnot's poem, the micro-variations of both the biological and linguistic are bound together in an ongoing correspondence of relations.

\section{Foodstuffs for the food chain dressed in light}

As Jarnot's Heliopolis unfolds, the nonhuman animals gain in prominence as poetic subjects, adding to the earlier animal poems with Song of the Chinchilla, You, Armadillo,

ning with the use of present simple tense, then adding an adverbial phrase, shifting to present continuous, and finally reorganizing syntax before a lyric speaker announces herself in relation to a reciprocal love" (Tardi 2019: 60). 
and Aardvark, the centerpiece and longest poem in the portfolio. Jarnot's Heliopolis is a sprawling place where the nonhuman comes to the fore, and all living things are "dressed in light"-an expression she deploys in all three of the aforementioned poemsperhaps alluding to the life-giving power of the sun, heavenly transcendence, or being part of a larger celestial body. What is more, Song of the Chinchilla and You, Armadillo may be reminiscent of Stein's Tender Buttons in how variable the punctuation can be, although Jarnot (2001: 59) leverages the second-person "You" to explore voice and address, and implicate the reader in her City of the Sun. Song of the Chinchilla begins:

You chinchilla in the marketplace in france you international chinchilla, chinchilla of the plains and mountains all in fur you fur of the chinchilla of the pont de neuf, selling wrist watches, on the oldest bridge of evolution that you are, you, chinchilla, going roadside towards the cars

The limited use of commas leaves the reader to insert pauses or emphasis within the line as well as find connections between elements and lines, and a verse such as "plains and mountains all in fur you fur of the / chinchilla" does not establish any firm referents. Are the plains and mountains "all in fur," i.e. fur-covered? Can such a relatively small animal like a chinchilla, in Jarnot's rendering, extend its fur onto such a gigantic scale? How would a transaction such as the selling of a wristwatch even work? And for whom? Does the "You" addressed at the beginning of the poem shift from the chinchilla itself being spoken to and then scale downward, as if through a poetic microscope? Similarly, You, Armadillo deftly uses voice and address to implicate the reader in this lyrical voyage:

You, armadillo, the dark and stately shape of armadillo, the street the shape of armadillo, the arm of the armadillo in the cask of snow, the cask of snow in armadillo in the taxi in the snow, the taxi cab of armadillo, the shape of texas like an armadillo, the snow that falls in texas in the armadillo snow, the armadillo running through the street to zoos in arm's length near the snow, the there you are where I am not an armadillo that does not light the way... (Jarnot 2001: 60) 
Much like Song of the Chinchilla, the "you" is an ambiguous and charged subject. Is it you, the reader? You, the armadillo? Could it be vocative or accusative? You, armadillo! As the poem develops, the categories confound with nouns in adjectival and tautological forms - "the armadillo snow" or "the armadillo armadillo"-and geographical distinctions implode as the animal armadillo shapes the landmass Texas, rather than serving as a kind of spirit animal for one of the largest states in the U.S.

Moreover, much like the lyric subject whose boundaries are blurred, so too is geography and scale. The locations and details accrue and expand: Heliopolis is not one fixed purely anthropocentric location but a dynamic interconnected and interdependent planet that is part of a solar system and galaxy. It can be New York, London, Paris, and Texas, which is to say, it can be anywhere that sustains life; and a relatively small animal such as an armadillo can be on par with "texas" or a chinchilla with "france," both of which Jarnot reduces to the lowercase form, thereby putting these locations on a level field with her poetic subjects.

Thus, Jarnot's poems (and poetic speakers) in Heliopolis can be read as enacting the Deleuzian (1987: 235) concept of "becoming-animal," as "the relationships between animals are bound up with the relations between man and animal, man and woman, man and child, man and the elements, man and the physical and microphysical universe.” Moreover, the Steinian recursive elements in Jarnot's poetry serve to reinforce this notion, as "to become is not to progress or regress along a series" (Deleuze \& Guattari 1987: 235) and, instead, is fundamentally "a phenomenon of bordering” (245). Aardvark, then, is the apotheosis of these considerations, and offers an allusively rich two-and-a-half page extended meditation on the porous borders between the human and nonhuman. The poem opens by establishing the sheer expansiveness of the aardvark, the Whitmanesque multitudes that it can contain:

aardvark that languishes on the edges of the margins where the margin walker walks, aardvark that you are the sky, sunken chested aardvark of the dark earth of the aardvark gone asleep, aardvark of the sea spray that is green, of the sea light in the afternoon with rain (Jarnot 2001: 62)

Jarnot's aardvark is both marginal and supernal, receding into the earth and a sea spray "in the afternoon with rain." The aardvark is elemental, yes, but not only. It is also proactive-"running towards the aardvark with the gun"; "aardvark that eats men"; and "unleashed like dogs"-taking agency and primacy in its environment. What is more, Jarnot's aardvark is "redolent" of rain, thunder, "lizards and the claws of things and men" and is a "vociferous drunk" (2001: 62-62). 
Apart from the array of actions the aardvark goes through, whether it be falling from airplanes, filling hotel rooms with aardvarks "arching as to fly," or riding trains, Jarnot alludes to external contexts and connections to the aardvark. None other than Federico Garcia Lorca and his concept of duende inform the poem ("great duende of the aardvark, / lesser duende of the aardvark"), which seems to suggest that the aardvark may operate as a kind of internalized Heliopolitan hobgoblin ${ }^{4}$, the powerful and irrational verve of art itself. That the duende of Jarnot's aardvark is both "greater" and "lesser" mirrors her toggling between humor and social critique, contradiction as convergence. These energies are not antithetical but two sides of the same coin.

In addition, much like in You, Armadillo or Song of the Chinchilla, where scales of animals and geography are often inverted, here Jarnot's aardvark is the "abraham lincoln of the aardvark," an "Aardvark with monkeys in your hair," and both "artichokes" and "electrical." The push-pull between these seemingly paradoxical visions of aardvarkness is perhaps best illustrated with the line "aardvark of the quick and also aardvark of the dead" (2001: 62). The allusion here is multivalent and could refer to Sam Raimi's 1995 film The Quick and the Dead, featuring Gene Hackman and Sharon Stone; or it could point to the King James version of the Bible, 2 Timothy 4:1: "I charge thee therefore before God, and the Lord Jesus Christ, who shall judge the quick and the dead at his appearing and his kingdom.” In the former, Jarnot is pointing the reader to a mildly entertaining film that was screening near the time Ring of Fire was written; in the latter, the poet could be suggesting that the multitudes of aardvarks (and perhaps the numerous other animals) are passing judgment on this world. In either case, she humorously adds "and also" between "the quick" and "the dead" to hinder this insight.

Although Jarnot may be able to elevate nearly invisible animals to poetic subjects and cleverly complicate simplistic taxonomies between species, this does not eliminate the pervasiveness of anthropocentrism. The difficulty poetry like Jarnot's encounters pertains, in part, to the ethical position of nonhuman animals: after all, what is the responsibility of the human (writer)? Cary Wolfe (2009: 567) argues that:

Rather than treat the animal as primarily a theme, trope, metaphor, analogy, representation, or sociological datum (in which, say, relations of class, or race, or gender get played out and negotiated through the symbolic currency of animality and species difference), scholars in animal studies, whatever their home disciplines, now appear to be challenged not only by the discourses and conceptual schemata that have shaped our understanding of and relations

4 What is more, Jarnot's duende could be seen as a dialogic consideration of Deleuze and Guattari's (1987: 247) demonic becoming-animal: "If becoming-animal takes the form of a Temptation, and of monsters aroused in the imagination by the demon, it is because it is accompanied, at its origin as in its undertaking, by a rupture with the central institutions that have established themselves or seek to become established." 
to animals but also by the specificity of nonhuman animals.... And that irreducibility of the question of the animal is linked complexly to the problem of animals' ethical standing as direct or indirect subjects of justice.

This issue is one that Jarnot appears to be keenly aware of-and attempts to address in the remaining poems in her Heliopolis.

\section{Right View, Right Action}

One may safely assume that Jarnot herself would poetically agree with Cary Wolfe's (2009: 568) assertion that, "[t]o put it bluntly, just because we study nonhuman animals does not mean that we are not continuing to be humanist-and therefore, by definition, anthropocentric”. In her poem Right View, she unambiguously writes:

The human animal that I am

is the human animal that I am

the view that I have is of

the human animal that I am

in the human room

(Jarnot 2001: 70)

No sooner does Jarnot focus our gaze on a Heliopolis with nonhuman animals at its center, prodding and provoking us to visualize and consider animals that might be marginalized in our discourse and from our human perspective, then she swiftly turns the poetic mirror back onto her readers. Critic Nick Selby (2005: 206), in his reading of The Right View, observes that

Jarnot's poetics clearly raises ethical questions about the space inhabited by the human as she asks us to see through the myths that normally ground us by describing us as at the centre of the perceptual universe.... [Jarnot] demonstrates that although the world might be seen to be transformed through human agency, no special status is thus conferred upon our relationship to the world.... to be human (and thus, presumably, to have lyric agency) merely means that we read the world from a human perspective.

I would add that, as I have previously argued, Coffee and whiskey drinking lemurs, wrist-watch-selling chinchillas, or taxi-cab hailing 
armadillos certainly may be absurd situations to contemplate, but these gestures act as more than just humorous poetic entertainment; they serve to draw our attention to these various animals. In some respects, Jarnot is deploying a tactic common to children's literature: humanizing the nonhuman to provoke a range of emotions. But choosing animals that lack a built-in literary or artistic audience or history, our gaze is doubly refracted-left to ponder the implausibility of the situations necessarily requires thinking about and visualizing the animals in conditions other than their typical surroundings, surroundings created by human activity. Compounding this with Jarnot's complex maneuvers between voice and address, mantra-like recursions, nonstandard punctuation, and inverted social dynamics, the poems produce ludic and hypnotic qualities as well as a site to contemplate moral engagement. (Tardi 2019: 65)

While the speaker in Right View recognizes inherently human flaws and a penchant for contradictory impulses ("the right view falls in love / with the wrong view"; "the human confusion / in its naturalness, tired"), in Right Labor the poet offers the possibility for agency coupled with optimism in writing: "What does not change / is the will to change / the humans on the train" (Jarnot 2001: 76). In Right Speech, Jarnot suggests a proactive form of hope with the lines "Love, which is meaning / compels speech" (Jarnot 2001: 72). For all of the formal acrobatics and absurdist humor in Ring of Fire, Jarnot aims to wrap her collection with a ring of possibility. Selby (2005: 207) sees this as demonstrative of a clear moral imperative and an eco-poetic concern in her work:

By questioning the ethical position we occupy as lyric subjects, Jarnot... meditate[s] upon poetic responsibility, on the role of the (woman) poet within the structures of power that underpin American mythologies.... [P]oetry does this, as we have already seen in the examples from Jarnot, by casting attention upon the very dissolving frontiers of its lyrical engagement with the world.... The lyric poem is ethical... because it can enact ecological ways of reading.

In this way, Jarnot can be seen as part of a long tradition of compassionate and engaged literature, echoing philosopher Jeremy Bentham's (1907: 311) famous remarks on how humans should regard other animals: "The question is not Can they reason?, nor Can they talk?, but Can they suffer?" This empathetic approach is similarly articulated two centuries later in Witold Gombrowicz's (1989: 27-28) Diary, when he confesses: “Today I am afraid-if this is the right word-of the suffering of a fly.... [P]ain is pain wherever it appears, equally horrifying in man as in a fly; in us the experience of pure suffering has become informed, our hell has become universal". In Jarnot's vision of Heliopolis, the 
same leveling and empathizing with pain holds true for humor or wonder, as we are all, in some sense, "dressed in light."

\section{In Its Glory Yet Will Be}

The famed novelist and critic William Gass in his introduction to a volume by Gertrude Stein imagined life as a volley between repetition and reorganization, as countless details are experienced "a thousand thousand times.” He concludes that:

We are not clocks, designed to repeat without remainder, to mean nothing by a tick, not even a coming tock, and so we must distinguish between merely mechanical repetition, in which there is no progress of idea, no advance or piling up of wealth, and that which seriously defines our nature, describes the central rhythms of our lives. (Gass 1973: 24-25)

Gass's remarks are no less true for Jarnot, whose deft use of repetition and recursion offer ludic and kaleidoscopic perspectives through nuance and intimate detail, for both humans and nonhumans. The poems in Jarnot's reimagining of Heliopolis call to mind Gaston Bachelard's The Poetics of Space, when he notes that "Sometimes the house of the future is better built, lighter and larger than the house of the past, so that the image of the dream house is opposed to that of the childhood home." In this way, Bachelard's house of the future, for Jarnot, works on both a macro- and micro-scale, as simultaneously a planet or cosmos and zoomed-in individuated ecosystems. And in perfectly Jarnotian fashion, the nonlinearity and recursion in her poems hardly discards the childhood (Steinian) home but instead renovates it in the service of a posthumanist critique as the nonhuman animals and poetic speakers "are at the same time creatures of imagined possibility and creatures of fierce and ordinary reality; the dimensions tangle and require response" (Haraway 2008: 4).

On a fundamental level, Lisa Jarnot's poetic exploration of the legendary city of Heliopolis is both a large- and small-scale rewriting and reconceptualization, which draws our attention to the fact that the location of "the advent of all being" would necessarily include all living things, of which humans only constitute a small fraction. As Giorgio Agamben (2004: 76) reminds us, "The stakes are now different and much higher, for it is a question of taking on as a task the very factical existence of peoples, that is, in the last analysis, their bare life." For Jarnot, the "City of the Sun" is neither an isolated urban center in ancient Egypt nor is it a vortex through which human achievement should be magnified. Rather, Heliopolis is similar to how Agamben (2004: 79) defines anthropogenesis: it "is what results from the caesura and articulation between human and animal." Jarnot's Heliopolis is an ongoing project, a megalopolis that stretches across space-time, a synonym for planet Earth, one of billions of dots in a galaxy. 


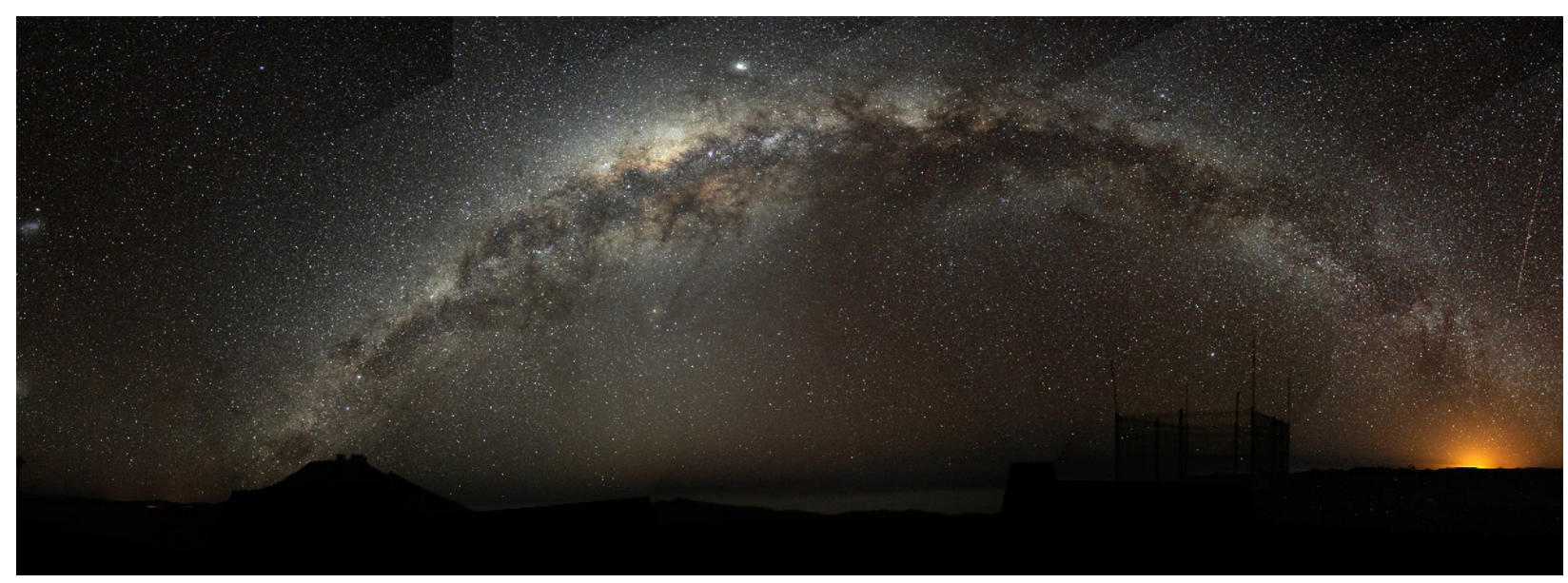

Fig. 1. Photo by Bruno Gilli/ESO

After all, as Jarnot (2001: 64) writes in her closing to the expansive poem "Aardvark":

with the element of the sun beams

that the elements of the aardvark

in its glory yet will be,

break light of the aardvark

in its dance

that in its dance

the numened aardvark brings.

Whether armadillo striations, the arched back of an aardvark about to fly or a chinchilla's fur shimmering, whether it is a kind of astral architecture or celestial horizon, or simply Cezannés "solar heat stored up and organized," the sky above Jarnot's Heliopolis is the place where living things look up at the stars in radial sublimity, and, in reciprocal acknowledgment, the stars look back.

\section{References}

Agamben, G. 2004. The Open. Stanford: Stanford University Press.

Bachelard, G. 2015. The Poetics of Space. New York: Penguin.

Bentham, J. 1907. An Introduction to the Principles of Morals and Legislation. Oxford: Clarendon Press.

Deleuze, G. \& Guattari, F. 1987. A Thousand Plateaus: Capitalism and Schizophrenia. Minneapolis: University of Minnesota Press. Dobrowolska, A. \& Dobrowolski, J. 2006 Heliopolis: Rebirth of the City of the Sun. Cairo: the American University in Cairo Press. 
Gass, W. 1973. "Introduction” for Gertrude Stein, The Geographical History of America or The Relation of Human Nature to the Human Mind. 24-25. New York: Vintage.

Gombrowicz, W. 1989. Diary (vol. 2). Evanston: Northwestern University Press.

Haraway, D. 2008. When Species Meet. Minneapolis: University of Minnesota Press.

Jarnot, L. 2001. Ring of Fire. Boston: Zoland Books.

Johnston, D. 2002. Book review. Chicago Review, vol. 47, no. 3: 139-141.

Kaufmann, D. 1999. Repetition, noise, and pleasure, or why I like John Yau and Lisa Jarnot. English Matters, no.1. 1-7.

Maso, C. 1995. The Art Lover. New York: Ecco Press.

Perloff, M. 1979. Poetry as Word-System: the Art of Gertrude Stein. American Poetry Review, vol. 8, no. 5 (Sept/Oct.): 33-43.

Raimi, S. 1995. The Quick and the Dead. Film.

Selby, N. 2005. Mythologies of 'Ecstatic Immersion': America, the Poem and the Ethics of Lyric in Jorie Graham and Lisa Jarnot. In: W. Blazek \& M. K. Glenday (eds.), American Mythologies: Essays on Contemporary Literature, 202-225. Liverpool: University of Liverpool Press.

Stein, G. 1914. Tender Buttons. New York: Claire Marie.

Tardi, M. 2019. 'Dressed Like Stars in the Blades of Night': On Lisa Jarnot's Poetics of Nonhuman Animals. In: P. Austin \& E. Rokosz-Piejko (eds.), Re-Imagining the Limits of the Human, 55-67. Berlin: Peter Lang.

Tompsett, D. 2014. Heliopolis: A City of Two Tales. http://www.vision.org/visionmedia/ history-ancient-egypt/77175.aspx. (4 March 2020)

Wolfe, C. 2009. Human, All too human. PMLA, vol. 124, no. 2: 564-575.

Zawacki, A. 2002. Book review. Boston Review, vol. 27. no. 1 : 1-4.

\section{Images}

Figure 1: Gilli, B./ESO. 2009. http://www.eso.org/public/images/milkyway/

$$
* * *
$$

Mark Tardi's books include The Circus of Trust, Airport music, and Euclid Shudders. Prologue, an award-winning cinepoem collaboration with Polish multimedia artist Adam Mańkowski, has been screened at film festivals throughout Europe and the United States. He was a writer-in-residence at MASS MoCA in January 2020 and his translation of The Squatters' Gift by Robert Rybicki is forthcoming from Dalkey Archive Press. A former Fulbright scholar, he is on faculty at the University of Lodz. 